\title{
A morphological and molecular analysis of the species diversity of the cichlid genus Petrochromis from Lake Tanganyika (Teleostei: Cichlidae)
}

\author{
Carl Mattsson \\ Department of Environmental Science and Analytical Chemistry (ACES), \\ Stockholm University, 10691 Stockholm, Sweden \\ E-mail: calle.mattsson@gmail.com
}

\begin{abstract}
A taxonomic revision of the cichlid fish genus Petrochromis endemic to Lake Tanganyika. All recognized taxa are herein described, one subspecies is given species status and five new species, viz. $P$. calliris, $P$. daidali, $P$. heffalumpus, $P$. lisachisme and $P$. paucispinis, are presented. $P$. calliris is described from 6 specimens from Cape Mpimbwe, and distinguished primarily by having a high number of both gill rakers on the lower limb of the first gill arch and vertebrae. P. daidali is described from 18 specimens from Cape Mpimbwe, Kansombo and Nkwazi point, and distinguished primarily by males having a labyrinth-like pattern on the head. P. heffalumpus is described from 7 specimens from Cape Mpimbwe, and distinguished primarily by its great size. P. lisachisme is described from 12 specimens from Cape Mpimbwe and Lyamembe, and distinguished primarily by having a high number of dorsal spines. P. paucispinis is described from 4 specimens from Halembe, and distinguished primarily by having a low number of dorsal spines. A revised key to Petrochromis is included. A phylogenetic tree hypothesis of the genus, based on molecular (mitochondrial cytochrome $b$ and d-loop) and morphological results show that jaw position and number of vertebrae are important diagnostic characters. Analyses suggest that the "ancestral Petrochromis" might have looked something like $P$. orthognathus.
\end{abstract}

Key words: meristics, morphometry, phylogeny, taxonomy 


\section{Introduction}

Lake Tanganyika (Fig. 1), the oldest of the Rift Valley lakes in east Africa, perhaps as old as 20 million years (Brichard, 1989), is the second largest freshwater lake in the world by volume and also the second deepest after Lake Baikal in Siberia (Ndembwike, 2006). It is one of the most important biodiversity hotspots in the world with an almost completely endemic lake fauna (Marijnissen, et al. 2006). Among the cichlids in the lake, the algal grazing niche is the most diverse and also has the highest number of species (Kolm, 2009).

Petrochromis is a genus of cichlid fishes endemic to Lake Tanganyika in East Africa (Yamaoka, 1983). They are highly specialized algal grazers that feed by scraping their teeth against rocks covered with epilithic growth (Yamaoka, 1983). Petrochromis inhabit shallow rocky shores (Yamaoka, 1983) but there is evidence to suggest that there are several species living in deeper water (Konings, 1996). Petrochromis are noted for their large size and for their aggression compared to other cichlids in the lake (Brichard, 1989).

Petrochromis was established by Boulenger (1898) with $P$. polyodon as the only species. Up till now six species and one subspecies have been described (Brichard, 1989). Petrochromis polyodon was based on four specimens from Kinyamkolo (presently Mpulungu) and Mbity Rocks off the southernmost coast of Lake Tanganyika (Boulenger, 1898). Boulenger (1902) described a new species, $P$. nyassae, based on a single specimen from Lake Nyassa (presently Lake Malawi). It was later found to be a specimen of $P$. polyodon with erroneous locality data as discussed by Matthes \& Trewavas (1960). The second valid species in the genus was described by Boulenger (1914) as P. fasciolatus, based on six specimens from Kapampa on the western shore and Kilewa Bay on the eastern shore of Lake Tanganyika. It was diagnosed by having numerous vertical stripes on its body (Boulenger, 1914). Poll (1948) described the third valid species, P. trewavasae, based on a single specimen from Moliro off the southwest coast of Lake Tanganyika, diagnosed by its lunate caudal fin. Matthes (1959) described the fourth valid species, $P$. orthognathus, based on 26 specimens from the northwest part of Lake Tanganyika, from Luhanga in the north to Lueba in the south. This species was diagnosed primarily by its isognathous jaws. The fifth valid species, $P$. famula, was described by Matthes \& Trewavas (1960) based on 37 specimens from different localities in Lake Tanganyika. The localities stretched all across the lake from Luhanga in the northwest to Kasanga in the southeast. Petrochromis famula was diagnosed primarily by its slightly isognathous jaws and also the lack of prominent cheek scales. Yamaoka (1983) described the sixth valid species, P. macrognathus, based on six specimens from Luhanga in the northwest part of Lake Tanganyika. It was diagnosed primarily by its projecting upper jaw. Brichard (1989) described a new subspecies of $P$. trewavasae called $P$. trewavasae ephippium. Type information and locality was not given in the original description. It was diagnosed by not having as long and filamentous fins as $P$. t. trewavasae. 
bioRxiv preprint doi: https://doi.org/10.1101/280263; this version posted March 12, 2018. The copyright holder for this preprint (which was not certified by peer review) is the author/funder, who has granted bioRxiv a license to display the preprint in perpetuity. It is made available under aCC-BY-NC-ND 4.0 International license.

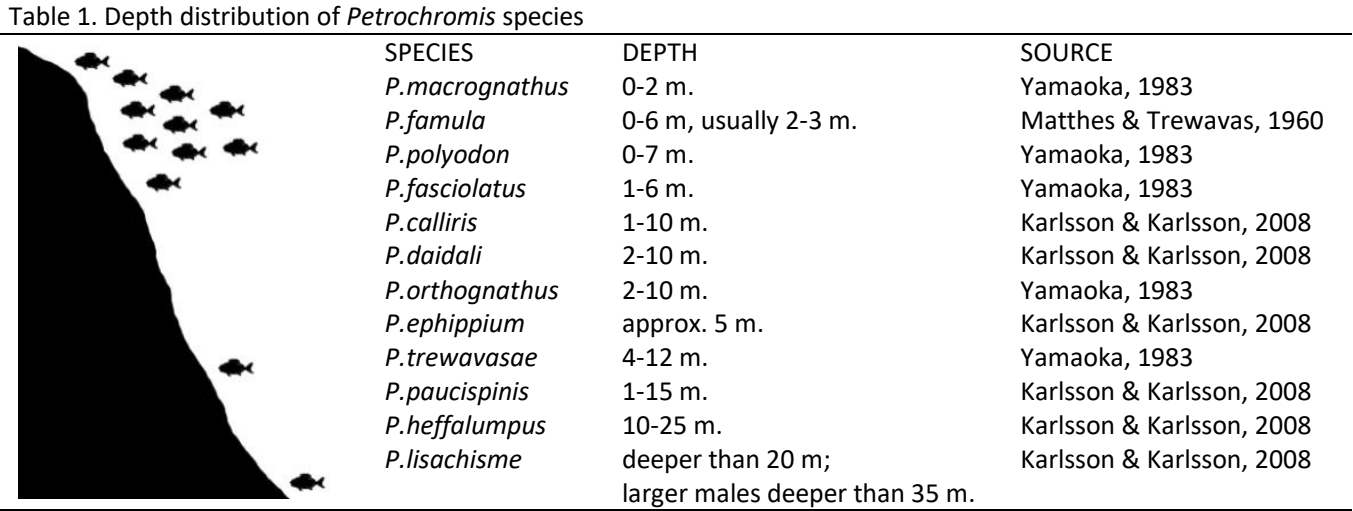

Note: The depth values with source Karlsson \& Karlsson, 2008 is unpublished data from field observations

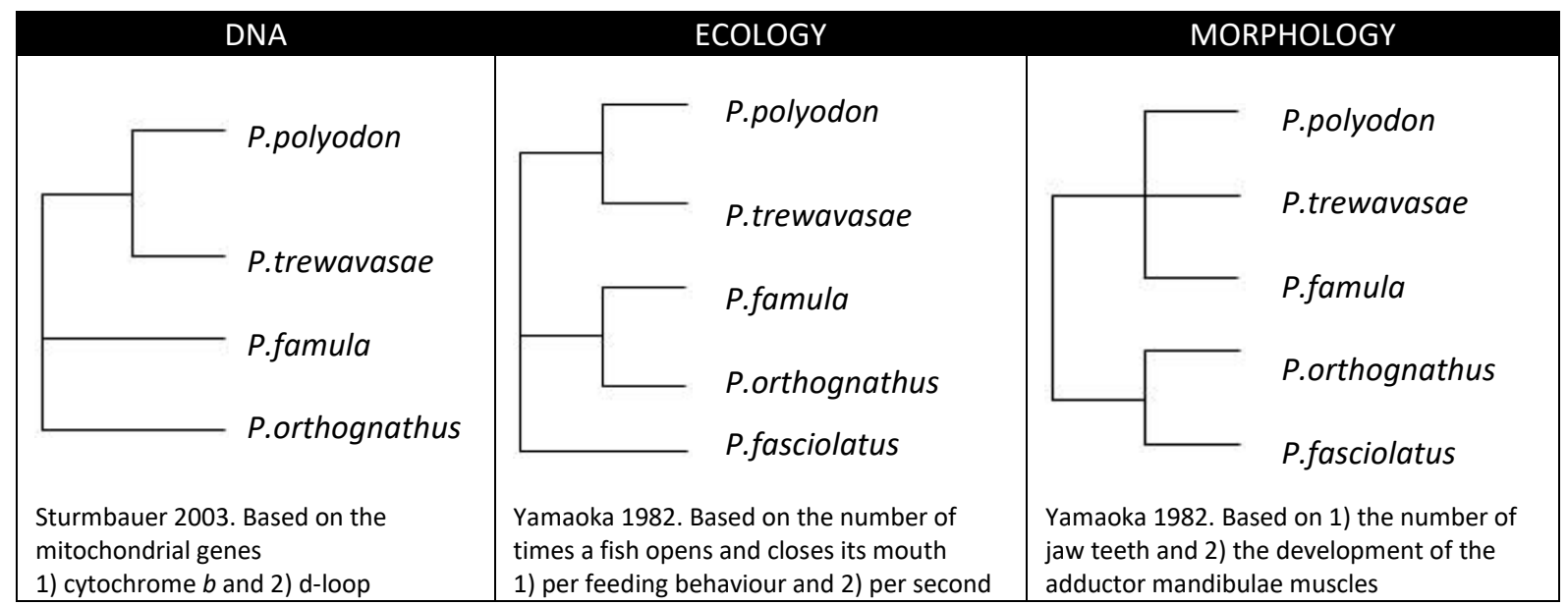

Fig. 2. Earlier hypotheses of the phylogeny of species of Petrochromis

Farías (2001) states that cytochrome $b$ is useful when assessing relationships between East African cichlids and Sturmbauer (2003) used both this gene and the gene d-loop in his molecular study on the tribe Tropheini, which includes e.g. Petrochromis and Tropheus. Since Sturmbauer (2003) only partially resolved the phylogeny of Petrochromis (Fig. 2) the present paper includes both molecular and morphological analyses for this purpose.

A revision of the genus is in order since several new species have been collected, notably some deep water species (Table 1), and the objective of the present paper is to review existing taxa, describe new species available, provide a revised key to the genus (Table 6) and provide a first relationship hypothesis (Fig. 7) for the expanded set of species.

\section{Materials \& Methods}

\section{Molecular analysis}

A total of 67 mitochondrial DNA sequences ( 28 cytochrome $b$ and 39 d-loop) were used for molecular phylogenetic analyses (Table 2). Complete mitochondrial cytochrome $b$ sequences (1137 bp) were obtained from 12 specimens of Petrochromis, including the potentially new species $P$. sp. Rainbow Kipili and $P$. sp. Yellow, sampled from live aquarium specimens and processed as fresh tissue; and from two specimens of Tropheus preserved in ethanol. Additional sequences of cytochrome $b$ and the mitochondrial d-loop (338 bp) were downloaded from the NCBI GenBank (http://www.ncbi.nlm.nih.gov/Genbank/). Those cytochrome $b$ sequences are only $402 \mathrm{bp} \mathrm{long}$, and the dataset adjusted accordingly.

DNA was extracted, using MoleStrips DNA tissue kit (Mole Genetics), with $100 \mu$ lysis buffer and $10 \mu \mathrm{l}$ proteinase $\mathrm{K}$ (conc. $10 \mathrm{mg} / \mathrm{ml}$ ), and then processed in a GeneMole automated DNA extraction instrument (Mole Genetics). A PCR was then performed using Illustra hot start mix RTG 
bioRxiv preprint doi: https://doi.org/10.1101/280263; this version posted March 12, 2018. The copyright holder for this preprint (which was not certified by peer review) is the author/funder, who has granted bioRxiv a license to display the preprint in perpetuity. It is made available under aCC-BY-NC-ND 4.0 International license.

(GE Healthcare) and a final primer concentration of $0.2 \mu \mathrm{M}$. The following primers were used: FishCytB-F (ACCACCGTTGTTATTCAACTACAAGAAC); TrucCytB-R (CCGACTTCCGGATTACAAGACCG); CytBi5R (GGTCTTTGTAGGAGAAGTATGGGTGGAA); CytBi7F (CTAACCCGATTCTTTGCCTTCCACTTCCT). Each reaction contained $4 \mu \mathrm{l}$ of DNA and $0.5 \mu \mathrm{l}$ of each primer. Sterile distilled water was added to give a final reaction volume of $25 \mu \mathrm{l}$. A touchdown PCR program started with initial denaturation at $94^{\circ} \mathrm{C}$ for $4 \mathrm{~min}$, followed by four cycles of $94{ }^{\circ} \mathrm{C}$ for $30 \mathrm{~s}, 55^{\circ} \mathrm{C}$ for $30 \mathrm{~s}, 72{ }^{\circ} \mathrm{C}$ for $1 \mathrm{~min}$, and another four-cycle phase and one 35 -cycle phase with identical temperatures and intervals, except that the annealing temperatures were reduced to 53 ${ }^{\circ} \mathrm{C}$ and $51{ }^{\circ} \mathrm{C}$ respectively. The program ended with $72{ }^{\circ} \mathrm{C}$ for $8 \mathrm{~min}$. Enzymatic PCR product clean-up was then done with Exonuclease I, E. Coli (Fermentas). Each PCR reaction mixture contained Exonuclease $(20 \mathrm{u})$ and FastAP thermosensitive alkaline phosphatase $(4 \mathrm{u})$. Cycle sequencing was performed using the ABI BigDye kit (Applied Biosystems) and the products were cleaned using DyeEx kit (Qiagen). The fragments were separated on an ABI 3130xl Genetic Analyzer (Applied Biosystems). Sequences were then assembled and checked with the Staden software (Staden \& Bonfield, 1998) and aligned manually with the BioEdit software (Hall, 1999). Regions of partially incomplete data at the beginning and end of the sequences were identified and excluded from subsequent analysis. Using the computer shell program PaupUp 1.0.3.1 (Calendini \& Martin, 2007), incorporating the software PAUP* 4.0 (Swofford, 2000), Treeview 1.6.6 (Page, 2001) and Modeltest 3.7 (Posada, 2008), a Maximum Likelihood analysis was performed on the data from d-loop and cytochrome $b$ respectively. Tree support was calculated using the bootstrap procedure, with 1.000 replicates, in PAUP*4.0 (Swofford, 2000). Then a Bayesian analysis of the two genes was also made using MrBayes 3.1.2 (Ronquist, 1991). Tropheus was used as outgroup for tree rooting.

Table 2. Gene sequence

Author; Source, Gene; Specimens; Tissue or GenBank numbers

Present paper; NRM; Cytochrome $b$; 10 Petrochromis and 2 Tropheus; tissue collection numbers 7099-7108, 6683, 6690

Sturmbauer et al., 2003; GenBank; Cytochrome b; 13 Petrochromis; AY301959- AY301970, AY301972

Wagner et al., unpublished; GenBank; Cytochrome $b$; 3 Petrochromis; EF679288- EF679289, EF679297

Verheyen et al., unpublished; GenBank; D-loop; 25 Petrochromis; AY574582- AY574585, AY574587, AY574589- AY574591, AY574594,

AY574597- AY574598, AY574601, AY574609- AY574612, AY574614- AY574615, AY574618- AY574619, AY574624, AY574629, AY574631, AY574633- AY574634

Sturmbauer et al., 2003; GenBank; D-loop; 13 Petrochromis; AY301946, AY301933-AY301944

Egger et al., 2007; GenBank; D-loop; 1 Tropheus; EF694276.1

\section{Morphological analysis}

All in all 14 measurements and 7 meristic counts (fin rays, scales \& vertebrae) were taken (Tables 4-5) from a total of 145 specimens. Measurements from 6 juveniles and 17 aquarium specimens were excluded from analysis. Methods for taking counts and measurements follow Barel et al. (1977) except for the following; pectoral fin length (from the tip of the longest fin ray to the base of the uppermost fin ray), length of lower jaw (from the anterior tip to the posterior end of the lower jaw), length of upper jaw (from the anterior tip to the posterior end of the upper jaw), labial depth (the deepest part of the upper lip), length of caudal peduncle (from the posterior measuring point of the standard length to the base of the last anal-fin ray) and length of last dorsal spine (from the tip to the base of the last dorsal spine). Vertebral counts were obtained from radiographs.

Seventeen characters were selected for morphological phylogenetic analysis, using Nexus Data Editor 0.5.0 (Page, 2001) to create the data matrix (Fig. 3, Table 3). The resulting Nexus file was then analyzed using PAUP*4.0 (Swofford, 2000) employing the heuristic tree search algorithm. Tropheus was used as outgroup for tree rooting. Tree support was calculated using the bootstrap procedure, with 10.000 replicates, in PAUP*4.0 (Swofford, 2000).

Specimens are preserved in the fish collection in the Swedish Museum of Natural History, Stockholm (NRM). Specimens, locality information, ornamental fish trade names, data on habitat and feeding behaviour of the five new species were provided by Magnus and Mikael Karlsson (in litt.) of the African Diving LTD. 
bioRxiv preprint doi: https://doi.org/10.1101/280263; this version posted March 12, 2018. The copyright holder for this preprint (which was

not certified by peer review) is the author/funder, who has granted bioRxiv a license to display the preprint in perpetuity. It is made available under aCC-BY-NC-ND 4.0 International license.

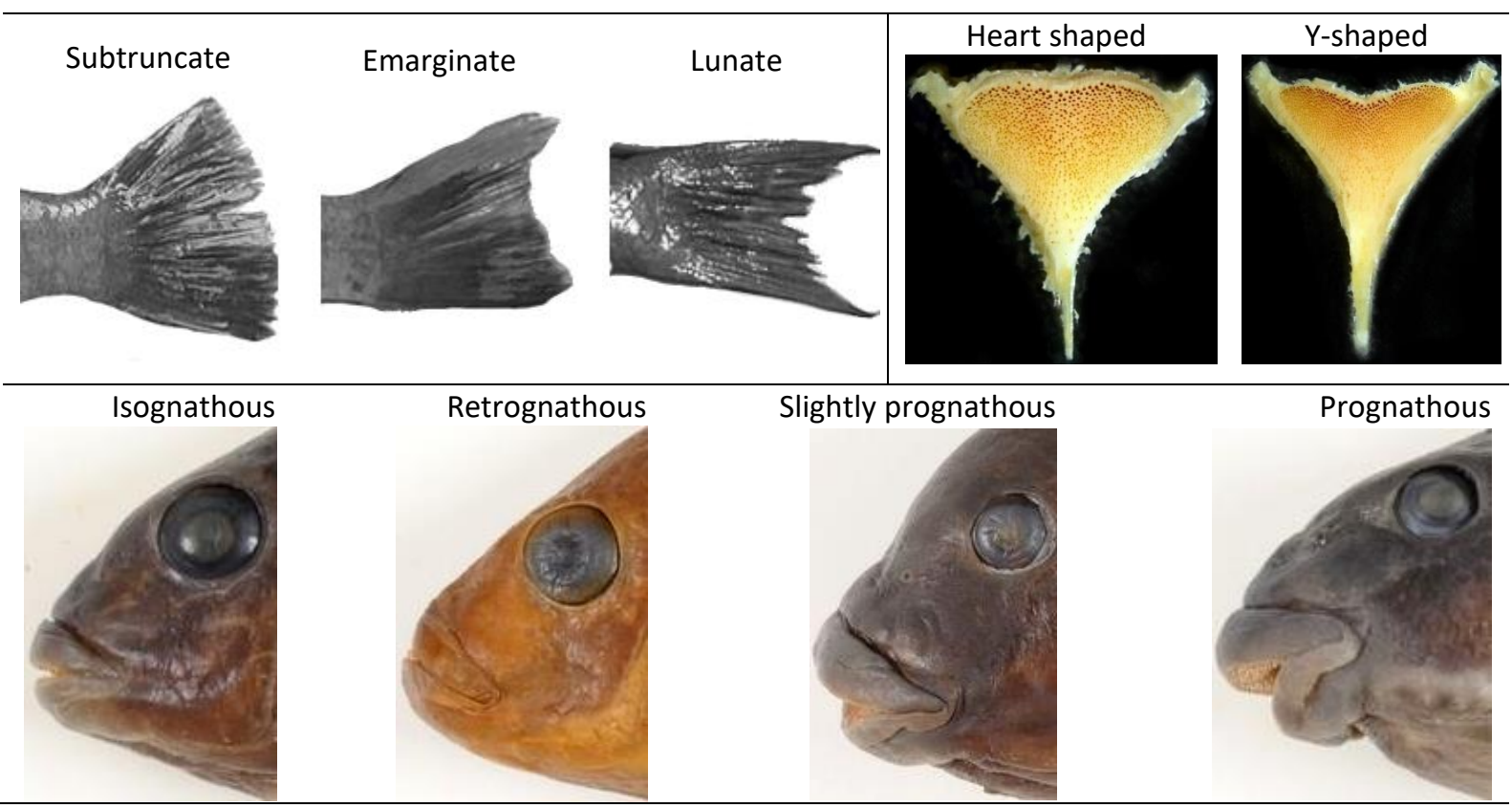

Fig. 3. Shape of caudal fin, lower pharyngeal jaw bone and upper jaw position in species of Petrochromis

Table 3. Data matrix based on morphological features of Petrochromis and Tropheus

\begin{tabular}{|lccccccccccccccccc}
\hline & 1 & 2 & 3 & 4 & 5 & 6 & 7 & 8 & 9 & 10 & 11 & 12 & 13 & 14 & 15 & 16 & 17 \\
\hline Tropheus sp. & 0 & 1 & 0 & 1 & 1 & 0 & 1 & 2 & 0 & 1 & 1 & 0 & - & 0 & 0 & 2 & 0 \\
P.polyodon & 1 & 1 & 1 & 1 & 1 & 0 & 1 & 0 & 1 & 0 & 0 & 0 & 1 & 1 & 1 & 0 & 2 \\
P.fasciolatus & 1 & 0 & 1 & 1 & 1 & 0 & 1 & 0 & 0 & 1 & 0 & 0 & 0 & 0 & 0 & 1 & 0 \\
P.trewavasae & 1 & 1 & 0 & 2 & 1 & 1 & 0 & 2 & 2 & 0 & 0 & 1 & 1 & 1 & 1 & 2 & 1 \\
\hline P.orthognathus & 0 & 0 & 1 & 0 & 1 & 0 & 1 & 1 & 0 & 1 & 1 & 1 & 0 & 0 & 0 & 0 & 0 \\
P.famula & 0 & 0 & 1 & 0 & 1 & 0 & 1 & 2 & 2 & 0 & 0 & 1 & 0 & 1 & 1 & 0 & 2 \\
\hline P.ephippium & 1 & 1 & 1 & 1 & 0 & 0 & 1 & 1 & 2 & 0 & 0 & 0 & 1 & 1 & 1 & 1 & 0 \\
P.macrognathus & 1 & 1 & 1 & 1 & 0 & 0 & 1 & 1 & 1 & 0 & 0 & 1 & 0 & 2 & 0 & 1 & 2 \\
\hline P.lisachisme & 1 & 1 & 1 & 2 & 0 & 1 & 0 & 1 & 1 & 1 & 1 & 1 & 1 & 1 & 2 & 2 & 1 \\
P.heffalumpus & 2 & 1 & 0 & 0 & 0 & 0 & 0 & 2 & 1 & 0 & 0 & 1 & 1 & 2 & 2 & 1 & 0 \\
\hline P.daidali & 1 & 1 & 1 & 1 & 0 & 0 & 0 & 2 & 2 & 0 & 0 & 0 & 1 & 1 & 1 & 1 & 1 \\
\hline P.paucispinis & 1 & 1 & 0 & 1 & 1 & 0 & 1 & 1 & 2 & 0 & 0 & 0 & 1 & 1 & 2 & 0 & 2 \\
\hline P.calliris & 2 & 1 & 1 & 0 & 1 & 0 & 0 & 1 & 1 & 0 & 0 & 1 & 1 & 1 & 0 & 1 & 1
\end{tabular}

\begin{tabular}{|c|c|c|}
\hline 1 & Vertebrae & 0) $\max 31$; 1) $\max 33$; 2) can have $34+$ \\
\hline 2 & Prognathous upper jaw & 0) no; 1) yes \\
\hline 3 & Gill rakers on lower limb of first arch & 0) $\max 12$; 1) can have 13 or more \\
\hline 4 & Caudal fin & 0) subtruncate; 1) emarginate; 2) lunate \\
\hline 5 & Pectoral fin & 0 max $33 \%$ of SL; 1 ) most specimens have $33+\%$ of SL \\
\hline 6 & Filamentous fins & 0) no; 1) yes \\
\hline 7 & Lateral-line scales & 0) can have $35+$; 1) less than 35 \\
\hline 8 & Correlation: vertebrae \& lateral-line scales & 0) $V \min =x-2 ; 1)[V \min =x-1] \&[V \max =x+3]$;2) $V \max =x+4$ \\
\hline 9 & Snout width & 0) $\max 17 \%$ of $\mathrm{SL}$; 1 ) all specimens with $17.1-19.9 \%$ of $\mathrm{SL} ; 2$ ) can have $20+\%$ of $\mathrm{SL}$ \\
\hline 10 & Teeth density & 0) high; 1) low \\
\hline 11 & Teeth in regular series & 0) no; 1) yes \\
\hline 12 & $\begin{array}{l}\text { Small scales present on base of dorsal fin } \\
\text { and/or anal fin }\end{array}$ & 0) no; 1) yes \\
\hline 13 & Lower pharyngeal jaw bone & 0) heart shaped; 1) Y-shaped \\
\hline 14 & Anal soft rays & $0)$ as few as $6 ; 1$ ) all specimens with $7-8 ; 2$ ) as many as 9 \\
\hline 15 & Body depth & 0) $<41 \%$ of SL; 1) all specimens with $41.0-42.9 \%$ of SL; 2 ) can have $43+\%$ of SL \\
\hline 16 & Dorsal spines & $0)$ as few as $17 ; 1$ ) all specimens with $18-19 ; 2$ ) as many as $20+$ \\
\hline 17 & Labial depth & $\begin{array}{l}\text { 0) specimens with less than } 3.3 \% \text { of SL present; } 1 \text { ) all specimens } 3.4-4.4 \% \text { of SL; } \\
\text { 2) specimens with more than } 4.5 \% \text { of SL present }\end{array}$ \\
\hline
\end{tabular}


bioRxiv preprint doi: https://doi.org/10.1101/280263; this version posted March 12, 2018. The copyright holder for this preprint (which was not certified by peer review) is the author/funder, who has granted bioRxiv a license to display the preprint in perpetuity. It is made available under aCC-BY-NC-ND 4.0 International license.

\section{Results}

Genus Petrochromis Boulenger, 1898

Diagnosis: Distinguished from other cichlids by having dental pads with a large number of tricuspid teeth on slender shafts (Yamaoka, 1983).

Description: Dorsal fin XVII-XXI, 8-11; anal fin III, 6-9; pectoral fin 13-15; number of lateral-line scales 30-38; vertebrae 30-35; gill-rakers on lower limb of first gill arch 10-15. Compact body and wide snout. Mouth large. Lips thick. Many tricuspid teeth with slender shafts in the jaws. Pelvic fins pointed with the first soft ray the longest. Egg dummies present on soft dorsal and anal fins. Caudal fin emarginate, subtruncate or lunate. Only a right gonad present.

Petrochromis polyodon Boulenger, 1898

Diagnosis: D. XVII-XIX, 8-10; A. III, 7-8; P. 13-14; gill-rakers on lower limb of first gill arch 12-14; lateral-line scales 30-34; vertebrae 31-33 (usually 32). Material examined: NRM 12884, 2 males, 113.3-137.0 mm SL, Congo, Luhanga. NRM 24157, 4 females and 1 male, 42.0-63.9 mm SL, Zambia, fishing camp midway between Lufubu and Mpulungu. NRM 51317, female, $170.3 \mathrm{~mm}$ SL, Tanzania, Molwe. NRM 60210, 6 males, 125.6-162.8 mm SL, Tanzania, Mpando point.

Petrochromis fasciolatus Boulenger, 1914

Diagnosis: D. XVIII-XIX, 8-10; A. III, 6-8; P. 13-14; gill-rakers on lower limb of first gill arch 11-13; lateral-line scales 30-34; vertebrae 31-33 (usually 32). Material examined: NRM 12757, male, 88.5 mm SL; NRM 12825, 2 males, 28.8-36.8 mm SL; Zambia, Nsumbu. NRM 12888, 2 males, 86.7-99.6 mm SL, Congo, Luhanga. NRM 51525, male, $103.3 \mathrm{~mm}$ SL, Tanzania, Udachi. NRM 51286, 7 males and 3 females, 103.1-124.6 mm SL; NRM 60215, female, 106.2 mm SL; Tanzania, Kansombo.

Petrochromis trewavasae Poll, 1948

Diagnosis: D. XIX-XX, 8-9; A. III, 7-8; P. 13-14; gill-rakers on lower limb of first gill arch 10-11; lateral-line scales 32-36; vertebrae 31-32. Material examined: NRM 13300, 8 females and 5 males, 73.2-105.0 mm SL, aquarium specimens. NRM 16893, 3 females, 105.1-128.2 mm SL, Tanzania, Kitwe point. NRM 17434, male, $30.5 \mathrm{~mm}$ SL, Tanzania, Kigoma.

Petrochromis orthognathus Matthes, 1959

Diagnosis: D. XVIII-XIX, 8-9; A. III, 6-8; P. 13-14; gill-rakers on lower limb of first gill arch 11-15; lateral-line scales 30-33; vertebrae 31. Material examined: NRM 17447, male, $118.0 \mathrm{~mm}$ SL, Tanzania, Kigoma. NRM 33695, 3 males and 1 female, 71.7-101.5 mm SL, aquarium specimens. NRM 51321, 10 males, 99.2-128.2 mm SL; NRM 57987, 8 males and 2 females, 93.0-109.4 mm SL; NRM 60213, male, $122.2 \mathrm{~mm}$ SL; Tanzania, Cape Mpimbwe.

Petrochromis famula Matthes \& Trewavas, 1960

Diagnosis: D. XVII-XVIII, 8-10; A. III, 8; P. 13-14; gill-rakers on lower limb of first gill arch 11-14; lateral-line scales 32-34; vertebrae 30-31 (usually 30). Material examined: NRM 51322, 6 females and 2 males, 97.3-136.2 mm SL; NRM 60214, male, 123.9 mm SL; Tanzania, Cape Mpimbwe.

Petrochromis macrognathus Yamaoka, 1983

Diagnosis: D. XVIII, 10; A. III, 7-9; P. 15; gill-rakers on lower limb of first gill arch 12-14; lateral-line scales 34; vertebrae 32-33 (usually 33). Material examined: NRM 51511, male, 89.8 mm SL, Tanzania, Molwe. NRM 59631, 4 males and 1 female, 137.3-150.0 mm SL, Tanzania, Katumbi point. 
bioRxiv preprint doi: https://doi.org/10.1101/280263; this version posted March 12, 2018. The copyright holder for this preprint (which was

not certified by peer review) is the author/funder, who has granted bioRxiv a license to display the preprint in perpetuity. It is made available under aCC-BY-NC-ND 4.0 International license.

Table 4. Proportional measurements as the percent of standard length (SL) in species of Petrochromis Data show ranges, means are in parenthesis

\begin{tabular}{|c|c|c|c|c|c|c|}
\hline & P.polyodon & P.fasciolatus & P.trewavasae & P.orthognathus & P.famula & P.macrognathus \\
\hline \# Specimens & $9 *$ & 15 & $3 * *$ & $23 * * *$ & 9 & 6 \\
\hline Standard length (mm) & 113.3-170.3 & $86.7-130.7$ & $111.0-128.2$ & $93.0-128.2$ & 97.3-136.2 & $89.8-150.0$ \\
\hline Head length & $33.1-38.7(35.3)$ & $30.8-34.7$ (32.7) & $32.9-36.3(34.5)$ & $31.9-35.6(33.4)$ & $34.3-38.2(36.2)$ & $34.6-35.9$ (35.5) \\
\hline Snout length & 18.0-20.1 (19.1) & $14.2-16.3(14.8)$ & $17.4-19.5$ (18.5) & $15.1-17.6(16.1)$ & 17.9-20.0 (18.9) & $16.5-19.5(18.5)$ \\
\hline Snout width & $17.1-19.3(18.4)$ & 14.9-16.7 (16.0) & $16.8-20.5$ (18.5) & $13.4-16.2$ (15.0) & $17.1-21.5$ (18.7) & 15.6-19.2 (17.9) \\
\hline Depth of body & $37.3-41.5$ (39.1) & $34.6-38.9(37.0)$ & $38.2-42.1$ (39.9) & $34.2-40.9(37.2)$ & $37.9-42.0(40.3)$ & $33.9-36.4$ (35.5) \\
\hline Eye diameter & $7.3-8.8(8.1)$ & $7.3-9.8(8.4)$ & $8.3-9.4(8.8)$ & 8.0-9.9 (8.7) & $7.1-8.5(7.8)$ & $7.0-9.0(7.7)$ \\
\hline Interorbital width & $10.9-12.8(11.6)$ & $10.7-12.2(11.4)$ & $11.3-11.8(11.6)$ & $9.5-12.1(10.7)$ & $12.2-13.4(12.8)$ & $10.1-11.2(10.6)$ \\
\hline Pectoral fin length & $28.8-34.0(32.0)$ & $23.3-33.5(28.5)$ & $30.1-32.3$ (31.4) & $30.0-35.0(32.5)$ & $34.6-38.1(36.0)$ & $25.5-29.3(27.6)$ \\
\hline Length of upper jaw & $13.7-16.6(15.4)$ & $10.4-13.6(12.5)$ & $12.2-14.9$ (13.7) & $11.1-13.9$ (12.6) & $13.5-17.0(15.7)$ & $13.4-16.0(14.9)$ \\
\hline Length of lower jaw & $12.0-14.0(13.0)$ & $10.6-15.1(12.5)$ & $10.8-14.0(12.2)$ & 10.6-12.9 (11.9) & $12.1-15.6(13.8)$ & $11.1-12.5$ (11.9) \\
\hline Labial depth & $3.8-4.8(4.4)$ & $2.8-3.8(3.3)$ & $4.1-4.4(4.3)$ & $2.8-4.3(3.6)$ & $4.6-5.1(4.8)$ & $4.4-4.8(4.6)$ \\
\hline Depth of caudal peduncle & $11.0-12.6(11.8)$ & $10.5-11.6(11.0)$ & $10.8-12.2(11.4)$ & $9.2-11.5(10.5)$ & $11.6-12.4(12.0)$ & $11.0-12.7(11.6)$ \\
\hline Length of caudal peduncle & $15.8-18.3(17.0)$ & $14.1-17.3$ (15.9) & $10.8-16.3(14.1)$ & $14.4-17.5$ (15.9) & $14.0-15.8(15.1)$ & $16.4-17.6(16.9)$ \\
\hline \multirow[t]{2}{*}{ Length of last dorsal spine } & $13.2-16.8(14.4)$ & 11.1-15.2 (13.3) & $14.6-15.0(14.8)$ & $12.2-15.0(13.6)$ & 13.6-15.6 (14.6) & $12.1-14.3(13.2)$ \\
\hline & P.ephippium & P.calliris & P.daidali & P.heffalumpus & P.lisachisme & P.paucispinis \\
\hline \# Spec & 8 & 6 & 18 & 7 & 12 & 4 \\
\hline Standard length (mm) & 127.5-156.9 & 153.2-179.0 & 129.3-207.1 & 195.4-281.2 & 133.9-202.8 & 128.7-156.3 \\
\hline Head length & $33.6-36.3(34.6)$ & $32.6-36.2(32.7)$ & $32.7-37.7(35.1)$ & $33.5-35.7(34.4)$ & $32.0-38.3(34.3)$ & $35.2-37.6(36.1)$ \\
\hline Snout length & $17.1-18.6(17.7)$ & 17.5-18.7 (18.0) & $17.4-19.6(18.7)$ & 18.4-19.8 (18.9) & $16.0-18.4(16.9)$ & 18.3-20.6 (19.3) \\
\hline Snout width & 16.8-20.6 (18.6) & 16.3-17.8 (16.9) & 16.9-21.9 (19.2) & 17.3-19.1 (17.8) & 16.7-19.7 (18.1) & $19.6-22.0(20.7)$ \\
\hline Depth of body & $37.2-41.1(39.4)$ & $36.5-39.9(38.5)$ & $35.8-41.5(38.8)$ & $38.9-45.4(41.7)$ & $39.1-44.3$ (41.1) & $40.8-46.1(43.2)$ \\
\hline Eye diameter & $7.8-9.4(8.4)$ & $6.5-8.1(7.2)$ & $6.5-8.5(7.5)$ & $6.1-7.1(6.6)$ & $6.8-9.6(7.7)$ & $7.8-8.3(8.0)$ \\
\hline Interorbital width & $12.2-13.2(12.6)$ & $11.7-12.9(12.2)$ & $11.3-14.2(12.3)$ & $12.4-15.0(13.6)$ & $11.7-13.3(12.4)$ & $12.2-14.4(13.2)$ \\
\hline Pectoral fin length & 29.0-31.6 (30.2) & 29.8-33.4 (31.5) & $27.8-33.0(31.0)$ & 28.0-31.6 (30.0) & 28.5-32.9 (30.0) & $30.3-34.8(32.7)$ \\
\hline Length of upper jaw & $13.4-15.2(14.2)$ & $13.2-15.1(14.3)$ & $13.7-17.7(15.3)$ & $13.3-17.3$ (14.9) & $13.8-15.9(14.8)$ & $14.6-17.1(15.7)$ \\
\hline Length of lower jaw & 11.3-13.4 (12.3) & $12.2-13.8(12.9)$ & $12.0-15.2(13.3)$ & 11.4-16.4 (13.6) & 11.4-13.7 (12.5) & 13.2-14.4 (13.6) \\
\hline Depth of labial & $3.0-4.2(3.7)$ & $3.5-4.4(4.0)$ & $3.7-4.5(4.1)$ & $3.4-4.3(4.0)$ & $2.9-4.2(3.5)$ & $3.8-4.6(4.2)$ \\
\hline Depth of caudal peduncle & $10.5-12.5$ (11.6) & $11.2-12.5(11.8)$ & 11.3-13.4 (12.0) & 11.4-16.4 (13.2) & $11.5-12.5(12.1)$ & 11.9-13.4 (12.6) \\
\hline Length of caudal peduncle & $14.4-17.3(15.8)$ & $16.2-17.4(16.7)$ & $15.7-18.4(17.1)$ & 16.7-18.7 (17.4) & $14.8-18.2(16.5)$ & $16.2-17.4(16.7)$ \\
\hline Length of last dorsal spine & $13.5-15.6(14.4)$ & $12.2-14.4(13.5)$ & $11.8-16.6(13.6)$ & 11.9-14.7 (13.2) & $12.2-16.0$ (13.9) & 13.5-14.4 (13.9) \\
\hline
\end{tabular}

Table 5. Frequency distribution of 7 meristic characters in species of Petrochromis

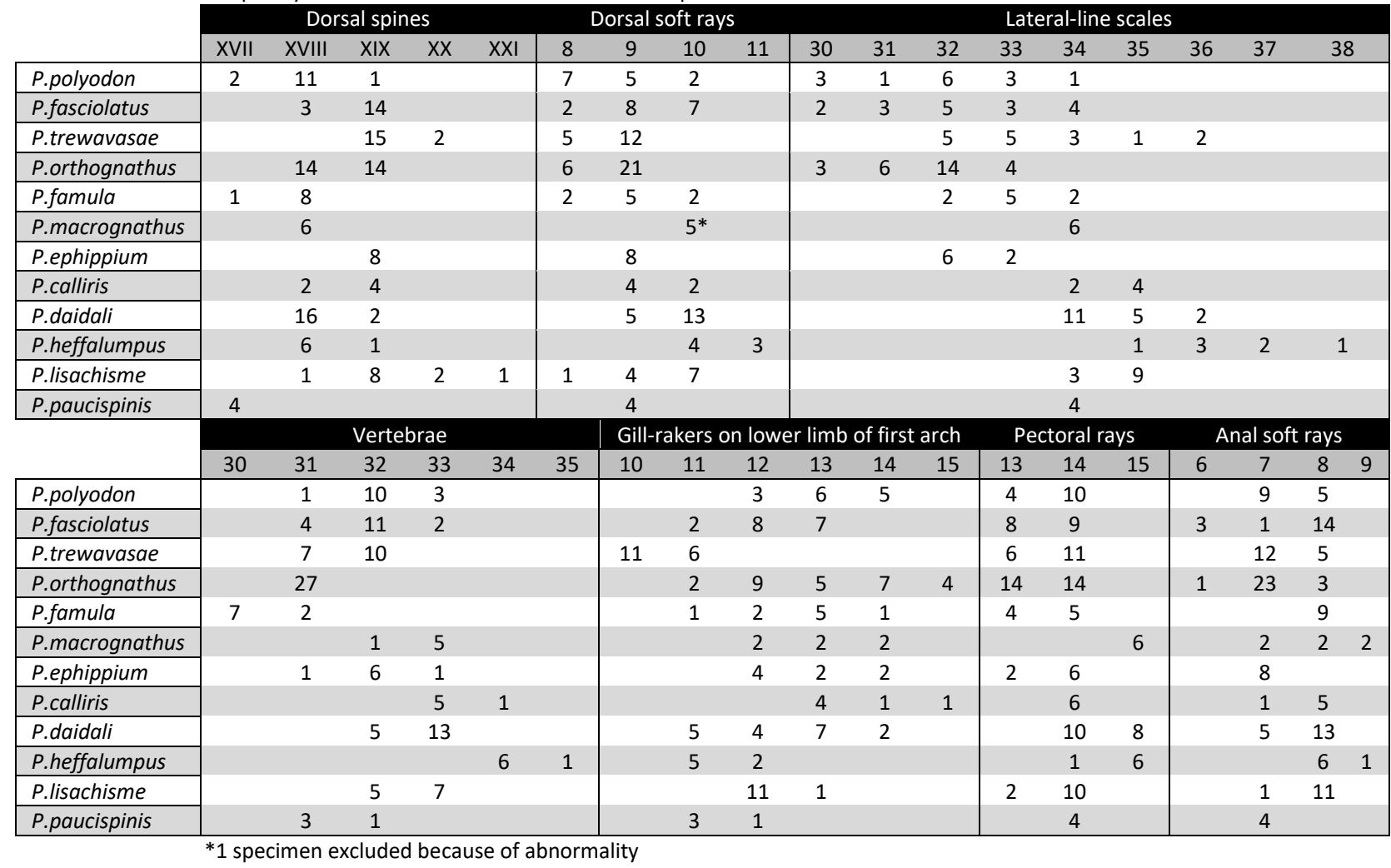


bioRxiv preprint doi: https://doi org/101101/280263; this version posted March 12, 2018. The copyright holder for this preprint (which was not certified by peer review) is the author/funder, who has granted bioRxiv a license to display the preprint in perpetuity. It is made available under aCC-BY-NC-ND 4.0 International license.

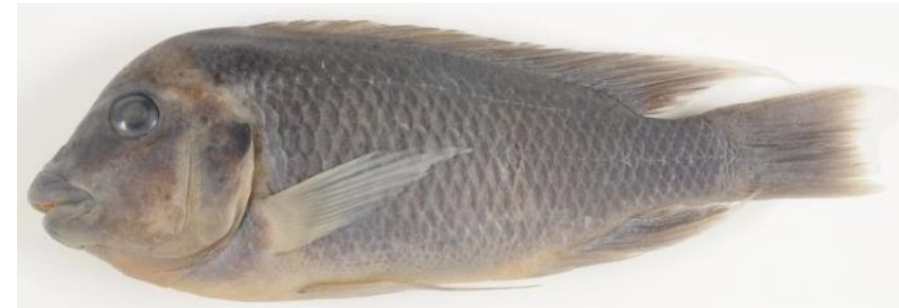

P. ephippium (Neotype: NRM 59565)

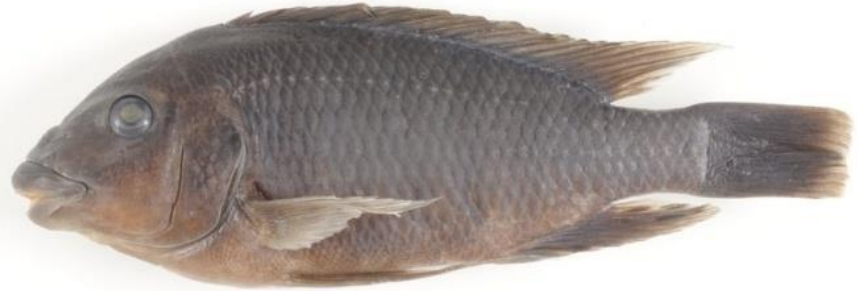

P. calliris (Holotype: NRM 57979)

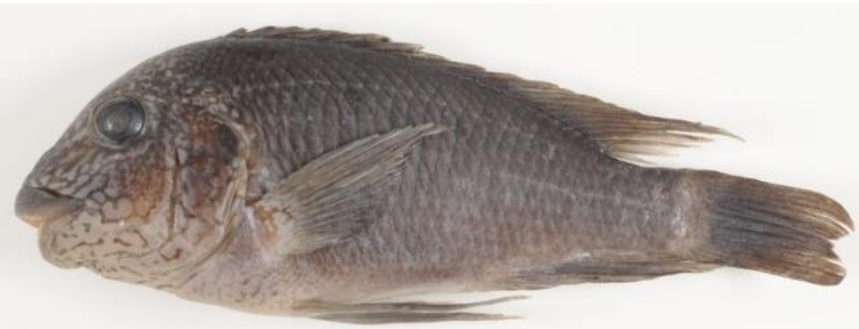

P. daidali (Holotype: NRM 58000)

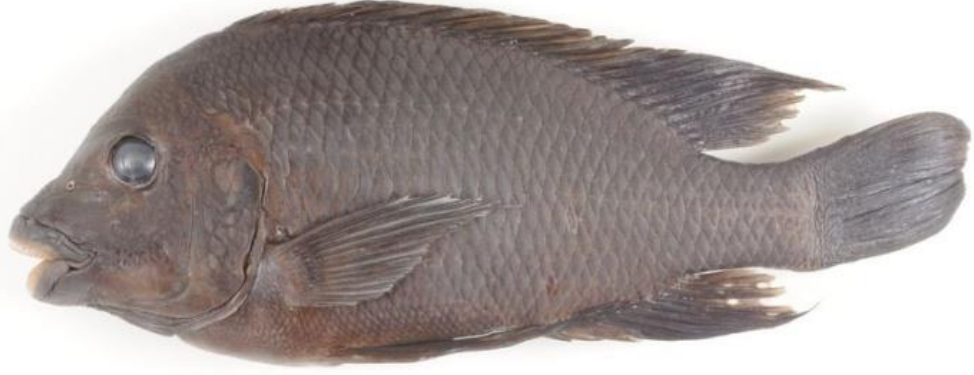

P. heffalumpus (Holotype: NRM 57992)

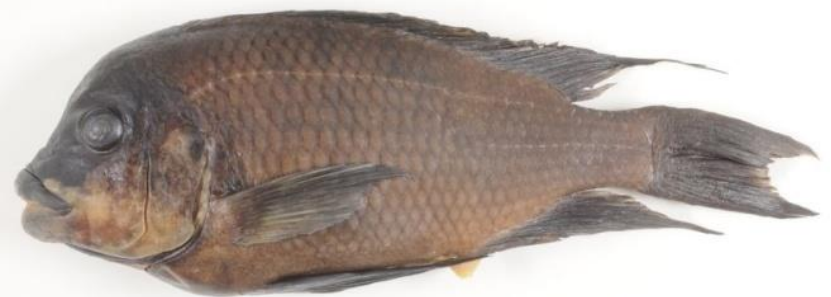

P. lisachisme (Holotype: NRM 57973)

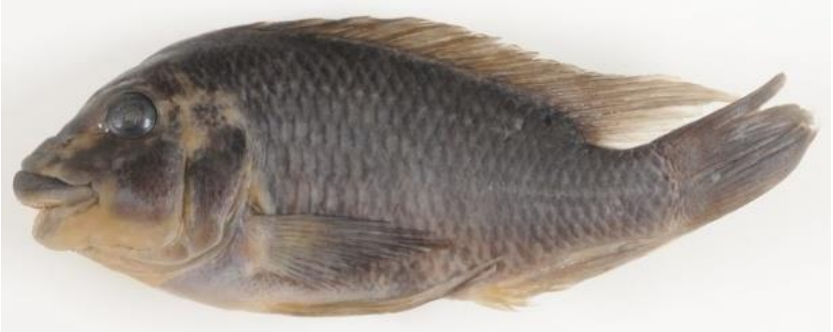

P. paucispinis (Holotype: NRM 57971)

Fig. 4. Holotypes of five new species of Petrochromis; and neotype of $P$. ephippium 
bioRxiv preprint doi: https://doi.org/10.1101/280263; this version posted March 12, 2018. The copyright holder for this preprint (which was not certified by peer review) is the author/funder, who has granted bioRxiv a license to display the preprint in perpetuity. It is made available under aCC-BY-NC-ND 4.0 International license.

Petrochromis ephippium Brichard, 1989

Diagnosis: D. XIX, 9; A. III, 7; P. 13-14; gill-rakers on lower limb of first gill arch 12-14; lateral-line scales 32-33; vertebrae 31-33 (usually 32). Material examined: NRM 51320, male, $152.1 \mathrm{~mm}$ SL; NRM 59565, 5 males and 2 females, 127.5-156.9 mm SL; Tanzania, Udachi, 2 Feb 2008, M. Karlsson. Remarks: Brichard (1989) described "P. t. ephippium" as a subspecies to P. trewavasae noting three major differences from the nominate subspecies; 1) not having as long and filamentous fins; 2) color brown to yellow-orange, instead of dark brown with white spots; 3 ) the geographical distribution of the two, with P.trewavasae restricted to a small coastal area on the west coast, approximately from Moliro to Kapampa, and that "P. t. ephippium", being more well spread, had only been found some way north of that and also in the southern part of the lake. Since I have examined east coast specimens of both of these species the geographical notion can be disregarded.

Brichard (1989) could find no significant morphometric differences between $P$. ephippium and $P$. trewavasae but $P$. ephippium has an emarginate caudal fin and 12-14 gill rakers on the lower limb of the first arch whereas $P$. trewavasae has a lunate caudal fin and 10-11 gill rakers.

Petrochromis ephippium is referred to in the ornamental fish trade as $P$. sp. Moshi. This I have deducted from studying live aquarium specimens and it being described as having a body color of brown to yellow-orange (Konings, 1988; Herrmann, 1985; Nemeth, 2009 unpubl.) and sometimes a saddle-like rectangular light-coloured patch under the dorsal fin (Brichard, 1989; Herrmann, 1985).

\begin{tabular}{|c|c|c|}
\hline $1 \mathrm{a}$ & Jaws equal anteriorly, or upper jaw projecting slightly & 2 \\
\hline $1 b$ & Upper jaw projecting in front of lower jaw notably & 3 \\
\hline 1c & Lower jaw projecting & P. fasciolatus \\
\hline $2 a$ & Upper jaw projecting slightly; Body deep; Tricuspid teeth in dense pad; Cheek scales not present on lower part of cheek & P. famula \\
\hline $2 b$ & Jaws equal anteriorly; Body not so deep; Tricuspid teeth not in a dense pad; Teeth showing regular series & P. orthognathus \\
\hline $3 a$ & Caudal fin subtruncate & 4 \\
\hline $3 b$ & Caudal fin lunate & 5 \\
\hline $3 c$ & Caudal fin emarginate & 6 \\
\hline $4 \mathrm{a}$ & Body color brown to green; Fin color often reddish; Body not so deep; Gill-rakers on lower limb of first arch 13-15 & P.calliris \\
\hline $4 \mathrm{~b}$ & Body color brown to blue; Fin color blue; Body deep; Gill-rakers on lower limb of first arch 11-12 & P. heffalumpus \\
\hline $5 a$ & Body color dark brown; Gill-rakers on lower limb of first arch 10-11; Tricuspid teeth in a dense pad & P. trewavasae \\
\hline $5 b$ & Body color intense red to greyish orange; Gill-rakers on lower limb of first arch 12-13; Tricuspid teeth not in a dense pad & P. lisachisme \\
\hline $6 a$ & $\begin{array}{l}\text { Body deep; Convexity of premaxillary ascending processes on snout less pronounced; No small scales present on } \\
\text { bases of dorsal and anal fins }\end{array}$ & 7 \\
\hline $6 b$ & $\begin{array}{l}\text { Body not so deep; Convexity of premaxillary ascending processes on snout much pronounced; Many small scales } \\
\text { present on bases of dorsal and anal fins; Pronounced concavity of chin region }\end{array}$ & P. macrognathus \\
\hline $7 a$ & Caudal fin emarginate, but closer to lunate than subtruncate; Snout wide, often $>19 \%$ of SL; At least 9 dorsal soft rays & 8 \\
\hline $7 \mathrm{~b}$ & $\begin{array}{l}\text { Caudal fin emarginate, but closer to subtruncate than lunate; Snout not so wide, often }<19 \% \text { of SL; As few as } 8 \text { dorsal soft } \\
\text { rays }\end{array}$ & P. polyodon \\
\hline $8 \mathrm{a}$ & Dorsal spines 18-19; Dorsal spines and rays combined 27-28 & 9 \\
\hline $8 \mathrm{~b}$ & Dorsal spines 17; Dorsal spines and rays combined 26; Body colored with orange and green, males also with blue & P.paucispinis \\
\hline $9 a$ & Lateral-line scales 34-36; Labyrinth pattern on face $\left(\sigma^{\top}\right)$ & P.daidali \\
\hline $9 \mathrm{~b}$ & Lateral-line scales 32-33; Body color brown to yellow-orange; Saddle-like rectangular light-coloured patch under dorsal fin & P.ephippium \\
\hline
\end{tabular}

\section{Five new species of Petrochromis}

Petrochromis calliris sp. nov.

Holotype: NRM 57979, male $160.1 \mathrm{~mm}$ SL, Tanzania, Cape Mpimbwe, S 7¹0969, E 3050227, rocky bottom with sand patches at a depth of $5 \mathrm{~m}$, net, 2 Feb 2008, M. Karlsson.

Paratypes: NRM 57978-57979, 2 males and 2 females, 156.8-176.8 mm SL; NRM 51319, male, 179.0 mm SL; same data as holotype.

Diagnosis: Distinguished from other Petrochromis by 1) greater number of vertebrae (33-34) compared to all other Petrochromis (30-33) except $P$. heffalumpus (34-35), 2) greater number of gill rakers on lower limb of first arch (13-15) compared to all other Petrochromis (10-14) except $P$. orthognathus (1115), 3) dorsal and anal fins in males have blue coloring near the edges.

D. XVIII-XIX, 9-10; A. III, 7-8; P. 14; gill-rakers on lower limb of first gill arch 13-15; lateral-line scales 34-35; vertebrae 33-34 (usually 33). 
bioRxiv preprint doi: https://doi.org/10.1101/280263; this version posted March 12, 2018. The copyright holder for this preprint (which was not certified by peer review) is the author/funder, who has granted bioRxiv a license to display the preprint in perpetuity. It is made available under aCC-BY-NC-ND 4.0 International license.

Body moderately deep. Snout profile of ascending processes of premaxillae moderately prominent. Upper jaw extending in front of lower jaw notably. Posterior margins of lip not reaching to vertical from anterior orbital rim. Tricuspid teeth on jaws in high density, not showing regular series. Cheek with 5-6 rows of scales. Scales present on opercle. Small scales present on base of dorsal fin. Last dorsal spine and 4th soft ray longest. Third anal spine and 4th soft ray longest. Posterior tips of dorsal and anal soft rays slightly filamentous. Pectoral fin shorter than head. Pelvic fin reaching first anal spine. Caudal fin subtruncate.

Color in life. Body color brown to green, often with blue and yellow areas. Fins tend to be reddish and to have blue coloring near the edges. Caudal fin often dark brownish.

Color in preservative. Body and fins dark brown.

Habitat and feeding behaviour: Petrochromis calliris occurs between Udachi and Kala Bay, usually at depths of 1-10 m. It is very territorial and males defend territories in shallow rocky areas. Usually it does not inhabit the same areas as $P$. macrognathus. Petrochromis calliris does not live quite as shallow as P. macrognathus but nevertheless the two species seem to compete for resources. Petrochromis calliris scrape algae off stones and rocks for food.

Remarks: Petrochromis calliris is similar to P. heffalumpus in the number of dorsal-fin spines (XVIIIXIX); the more numerous vertebrae, and the subtruncate caudal fin.

In the ornamental fish trade $P$. calliris is referred to as Petrochromis sp. Kasumbe rainbow.

Petrochromis daidali sp. nov.

Holotype: NRM 58000, male 159.7 mm SL, Tanzania, Nkwasi Point, S $6^{\circ} 25447$, E 29²73257, rocky bottom with sand patches at a depth of $5 \mathrm{~m}$, net, 17 Dec 2007, M. Karlsson.

Paratypes: NRM 58000, 2 males and 1 female, 129.3-153.1 mm SL, same data as holotype. NRM 57983, 4 males, 147.0-189.7 mm SL; NRM 51318, male, $207.1 \mathrm{~mm}$ SL; Tanzania, Cape Mbimbwe, 7.10969 ${ }^{\circ}$ S, $30.50227^{\circ} \mathrm{E}, 2$ Feb 2008, M. Karlsson. NRM 51287, 5 males and 3 females, 139.8-187.0 mm SL; NRM 60212, female, 197.3 mm SL; Tanzania, Kansombo, M. Karlsson.

Diagnosis: Distinguished from other Petrochromis by 1) a slightly increased number of lateral-line scales (34-36) compared to all other Petrochromis (30-35) except P. heffalumpus (35-38) and $P$. trewavasae $(32-36), 2)$ a slightly increased number of pectoral rays (14-15) compared to all other Petrochromis (13-14) except $P$. heffalumpus (14-15) and P. macrognathus (15), 3) males have a labyrinth pattern on their head.

D. XVIII-XIX, 9-10; A. III, 7-8; P. 14-15; gill-rakers on lower limb of first gill arch 11-14; lateralline scales 34-36; vertebrae 32-33 (usually 33).

Body deep. Snout profile of ascending processes of premaxillae moderately prominent. Upper jaw extending in front of lower jaw notably. Posterior margins of lip not reaching to vertical from anterior orbital rim. Tricuspid teeth on jaws in higher density, not showing regular series. Cheek with 4-5 rows of scales. Scales present on opercle. Last dorsal spine and 4th soft ray longest. Third anal spine and 3rd soft ray longest. Posterior tips of dorsal and anal soft rays not filamentous. Pectoral fin shorter than head. Pelvic fin reaching first anal spine. Caudal fin emarginate.

Color in life. Petrochromis daidali have many colormorphs but generally males have a blue body and also a labyrinth pattern on their head. Brown and green color varieties can also be found. Females have less conspicuous colors than males, often greyish green. In different locations you can find different shades of blue amongst the male populations. In Cape Mpimbwe they are steely blue, in Kipili they are dark blue, in Mtosi they are shining blue, in Ninde they are blue with whitish spots on the back and at Izinga Island they have a blue head and a yellow body.

Color in preservative. Body and fins greyish brown. Face pattern still visible although slightly faded. Habitat and feeding behaviour: Petrochromis daidali are usually found at depths of 2-10 m. Both sexes are fiercely territorial and prefer a rocky environment with stones and boulders. Especially males continually patrol their territory which is a $15-25 \mathrm{~m}^{2}$ large area which often includes at least some caves. In shallower waters the territories are smaller and the number of competing males increases. Petrochromis daidali scrape algae off stones and boulders for food.

Remarks: Petrochromis daidali is similar to P. polyodon in morphometry (Table 4) and Karlsson \& Karlsson (2008) inform me that $P$. daidali is sometimes mistaken for $P$. polyodon. The most conspicuous thing about $P$. daidali is the unique labyrinth-like face pattern present on most males. In the ornamental fish trade $P$. daidali is referred to as Petrochromis sp. Texas. 
bioRxiv preprint doi: https://doi.org/10.1101/280263; this version posted March 12, 2018. The copyright holder for this preprint (which was not certified by peer review) is the author/funder, who has granted bioRxiv a license to display the preprint in perpetuity. It is made available under aCC-BY-NC-ND 4.0 International license.

Petrochromis heffalumpus sp. nov.

Holotype: NRM 57992, male 281.6 mm SL, Tanzania, Cape Mpimbwe, S 7¹0969, E 3050227, rocky bottom with sand patches at a depth of $15 \mathrm{~m}$, net, 2 Feb 2008, M. Karlsson.

Paratypes: NRM 57989-57991, 3 females, 195.4-235.8 mm SL; NRM 57993-57994, 2 males, 263.9269.2 mm SL; NRM 51316, male, $281.2 \mathrm{~mm} \mathrm{SL}$; same data as holotype.

Diagnosis: Distinguished from other Petrochromis by 1) greater size (195.4-281.6 mm SL instead of $<209.8 \mathrm{~mm} \mathrm{SL}$ ), 2) greater number of lateral-line scales (35-38 instead of 30-36), 3) greater number of vertebrae (34-35 instead of 30-34), 4) greater number of dorsal soft rays (10-11 instead of 8-10), 5) caudal fin flattened horizontally on top and bottom.

D. XVIII-XIX, 10-11; A. III, 8-9; P. 14-15; gill-rakers on lower limb of first gill arch 11-12; lateralline scales 35-38; vertebrae 34-35 (usually 34).

Body deep, especially in male specimens. Snout profile slightly humped by ascending processes of premaxillae. Upper jaw extending in front of lower jaw notably. Posterior margins of lip not reaching to vertical from anterior orbital rim. Tricuspid teeth on jaws in high density, not showing regular series. Cheek with 5-6 rows of scales. Scales present on opercle. Small scales present on bases of dorsal and anal fins. Last dorsal spine and 5th soft ray longest. Third anal spine and 4th soft ray longest. Posterior tips of dorsal and anal soft rays not filamentous. Pectoral fin shorter than head. Pelvic fin reaching anal spines, even reaching slightly beyond the anal spines in larger male specimens. Caudal fin subtruncate.

Color in life. Body brown to blue. Fins tend to be blue and become darker further out from the body.

Color in preservative. Body and fins dark brown.

Habitat and feeding behaviour: Petrochromis heffalumpus occurs between Lyamembe and Izinga island, usually at depths of 10-25 m. It prefers an environment with large boulders and sand patches. Males are fiercely territorial and reside near a large cave that they can protect. Petrochromis heffalumpus scrape algae off large flat stony surfaces.

Remarks: Petrochromis heffalumpus share a number of characteristics with P. macrognathus. It has a similar number of dorsal spines, dorsal soft rays, pectoral rays and anal soft rays. The snout profile of $P$. heffalumpus is not quite as pronounced as $P$. macrognathus but nevertheless shows a similar hump. Petrochromis heffalumpus differs from P. macrognathus in that it has a deeper body. Petrochromis macrognathus also has a proportionally wider snout, fewer vertebrae and fewer lateral-line scales. Petrochromis heffalumpus is also similar to $P$. calliris in that they have a similar number of dorsal spines and vertebrae and also they both have a subtruncate caudal fin. The body proportions of these two species are also closer to each other than if you compare them to P. macrognathus.

In the ornamental fish trade P. heffalumpus is referred to as Petrochromis sp. Blue giant.

Petrochromis lisachisme sp. nov.

Holotype: NRM 57973, male $194.3 \mathrm{~mm} \mathrm{SL}$, Tanzania, Lyamembe, $6.46771^{\circ} \mathrm{S}, 29.93698^{\circ} \mathrm{E}$, rocky bottom with sand patches at a depth of $35 \mathrm{~m}$, net, 19 Jan 2008, M. Karlsson.

Paratypes: NRM 57995-57996, 4 males and 2 females, 133.9.5-187.4 mm SL; NRM51315, male, 176.8 mm SL; Tanzania, Cape Mbimbwe, $7.10969^{\circ} \mathrm{S}, 30.50227^{\circ} \mathrm{E}, 2$ Feb 2008, M. Karlsson. NRM 5797357974, 4 males, 194.1-209.8 mm SL, same data as holotype.

Diagnosis: Distinguished from other Petrochromis by 1) greater number of dorsal spines (XVIII-XXI instead of XVII-XX), 2) having a lunate caudal fin ( $P$. trewavasae shares this trait), 3) males have a distinct forehead which also gives the jaws a protruded appearance.

D. XVIII-XXI, 8-10; A. III, 7-8; P. 13-14; gill-rakers on lower limb of first gill arch 12-13; lateralline scales 34-35; vertebrae 32-33.

Body deep. Snout profile slightly humped by ascending processes of premaxilla. Upper jaw prognathous. Posterior margins of lip not reaching to vertical from anterior orbital rim. Tricuspid teeth on jaws in low density, showing regular series. Cheek with 4-6 rows of scales. Scales present on opercle. Small scales present on base of dorsal fin. Last dorsal spine and 4th soft ray longest. Third anal spine and 4th soft ray longest. Posterior tips of dorsal and anal soft rays slightly filamentous. Pectoral fin shorter than head. Pelvic fin reaching first anal spine or slightly beyond. Caudal fin lunate.

Color in life. Body ranging from intense red, with a black patch around the eye and chin; to orange, occasionally with yellow spots on the fins; to greyish green. Fins in the intense red variety tend to be dark whereas in other color varieties the fins tend to be the same color as the body. 
bioRxiv preprint doi: https://doi.org/10.1101/280263; this version posted March 12, 2018. The copyright holder for this preprint (which was not certified by peer review) is the author/funder, who has granted bioRxiv a license to display the preprint in perpetuity. It is made available under aCC-BY-NC-ND 4.0 International license.

Color in preservative. Specimens from Cape Mpimbwe; body and fins greyish brown. Specimens from Lyamembe; body brown and fins dark brown, head with dark brown face and a light grey patch around the eye and chin.

Habitat and feeding behaviour: Petrochromis lisachisme occurs between Bulu Point and Kala Bay, usually at depths of 20-35 m. Adults are found only below $20 \mathrm{~m}$ and larger males, $20-25 \mathrm{~cm}$, only below $35 \mathrm{~m}$. It prefers an environment with boulders and sand patches. It is less territorial than most other Petrochromis and they patrol a relatively large area which often includes at least some caves. The spawning area is created against a large rock in the form of a half crater in the sand. Petrochromis lisachisme scrape algae off stony surfaces and also eat phytoplankton.

Remarks: Petrochromis lisachisme is similar to Petrochromis trewavasae in having long filamentous fins and a lunate caudal fin. They are also the only two Petrochromis with as many as 20 dorsal spines. Field observations suggest that the red color of $P$. lisachisme is more intense in more northern localities. The most intense red color is present in specimens from Lyamembe and Bulu point. Specimens from Cape Mpimbwe are orange, and in Kala Bay specimens are greyish.

In the ornamental fish trade $P$. lisachisme is referred to as Petrochromis sp. Red.

Petrochromis paucispinis sp. nov.

Holotype: NRM 57971, male $156.3 \mathrm{~mm}$ SL, Tanzania, Halembe, S $5^{\circ} 73712$, E 2992167, rocky bottom with sand patches at a depth of $5 \mathrm{~m}$, net, 8 Jan 2008, M. Karlsson.

Paratypes: NRM 57971, 2 females and 1 male, 128.7-144.8 mm SL, same data as holotype.

Diagnosis: Distinguished from other Petrochromis by 1) fewer number of dorsal spines (XVII) compared to all other Petrochromis (XVIII-XXI) except P. polyodon (XVII-XIX) and P. famula (XVIIXVIII), 2) fewer number of dorsal spines and rays combined (26) compared to most other Petrochromis (generally 27-29) except $P$. polyodon (26-28), 3) greater snout width (mean $20.7 \%$ of SL) compared to all other Petrochromis species (with means of 15.0-19.2\% of SL).

D. 17, 9; A. III, 7; P. 14; gill-rakers on lower limb of first gill arch 11-12; lateral-line scales 34; vertebrae 31-32 (usually 31 ).

Body deep. Snout profile of ascending processes of premaxillae moderately prominent. Upper jaw extending in front of lower jaw notably. Posterior margins of lip almost reaching to vertical from anterior orbital rim. Tricuspid teeth on jaws in high density, not showing regular series. Cheek with 4-6 rows of scales. Scales present on opercle. Last dorsal spine and 4th soft ray longest. Third anal spine and 3rd soft ray longest. Posterior tips of dorsal and anal soft rays not filamentous. Pectoral fin shorter than head. Pelvic fin reaching first anal spine. Caudal fin emarginate.

Color in life. Body blue and green with orange patches, the ventral part silvery, in males. Body green with vague orange patches in females. Fin color orange in both sexes.

Color in preservative. Body and fins greyish brown.

Habitat and feeding behaviour: Petrochromis paucispinis occurs between Karilani Island to Mayobozi, usually at depths of 1-15 m. Both sexes are fiercely territorial and are especially aggressive towards other P. paucispinis. Territories are $10-20 \mathrm{~m}^{2}$, consist of rocky caves and are usually in shallower water than $10 \mathrm{~m}$. Petrochromis paucispinis scrape algae off stones for food.

Remarks: Petrochromis paucispinis is similar to $P$. polyodon and all seven meristic characters overlap (Table 5). Petrochromis paucispinis tend to have slightly fewer dorsal spines, vertebrae and gill rakers on the lower limb of the first arch, but often has more lateral-line scales than P. polyodon. In the ornamental fish trade P. paucispinis is referred to as Petrochromis sp. Kasumbe. 
bioRxiv preprint doi: https://doi.org/10.1101/280263; this version posted March 12, 2018. The copyright holder for this preprint (which was not certified by peer review) is the author/funder, who has granted bioRxiv a license to display the preprint in perpetuity. It is made available under aCC-BY-NC-ND 4.0 International license.

\section{Phylogenetic analysis}

The morphological matrix (Table 3) yielded a strict consensus tree (Fig. 5) with P. orthognathus, $P$. fasciolatus and $P$. famula as the three species most closely related to the outgroup Tropheus. No significant support could be found for this tree. One character needing further explanation is the correlation between vertebrae and lateral-line scales (character 8 in Table 3). Working with the hypothesis that all Petrochromis would have approximately the same number of vertebrae (V) as lateralline scales (L) I correlated these two for each specimen (Table 7). Vmin is the least amount of lateralline scales compared to the number of vertebrae, on any single specimen, within a species, Vmax being the opposite. The results show that most species have more lateral-line scales than vertebrae, excluding some specimens of $P$. polyodon, $P$. fasciolatus and $P$. orthognathus, and that no species has a Vmin value below -2 or a Vmax value of more than 4 . This can be described as $[\mathrm{V}=(\mathrm{L}+1) \pm 3]$.

The Maximum Likelihood and Bayesian trees created in the molecular analyses are shown in Figure 6 . The cytochrome $b$ analyses favour $P$. sp. Yellow as the sister group of all other Petrochromis, and $P$. famula as the sister group of all Petrochromis excluding $P$. sp. Yellow. In the d-loop analyses both trees favour $P$. famula and $P$. orthognathus as the sister group of all other Petrochromis. Also the d-loop Maximum Likelihood tree favours $P$. fasciolatus as the sister group of all other Petrochromis excluding $P$. famula and $P$. orthognathus.

Combined the morphological tree and the four molecular trees place P. orthognathus and P. famula (clade $A$ ) as the sister group of all other Petrochromis. Some support is also found that $P$. fasciolatus (clade $B$ ) is the sister group of all other Petrochromis excluding $P$. famula and P. orthognathus (clade $C)$. $P$. sp Yellow is here excluded due to insufficient data.

Table 7. Number of vertebrae (V) compared to the number of lateral-line scales

\begin{tabular}{lrr}
\hline & Vmin & Vmax \\
\hline P. polyodon & -2 & 3 \\
P. fasciolatus & -2 & 2 \\
P. trewavasae & 0 & 4 \\
P. orthognathus & -1 & 2 \\
P. famula & 1 & 4 \\
P. macrognathus & 1 & 2 \\
$P$. ephippium & 0 & 1 \\
P. calliris & 1 & 2 \\
$P$. daidali & 1 & 4 \\
$P$. heffalumpus & 1 & 4 \\
$P$. lisachisme & 1 & 3 \\
P. paucispinis & 2 & 3 \\
\hline
\end{tabular}

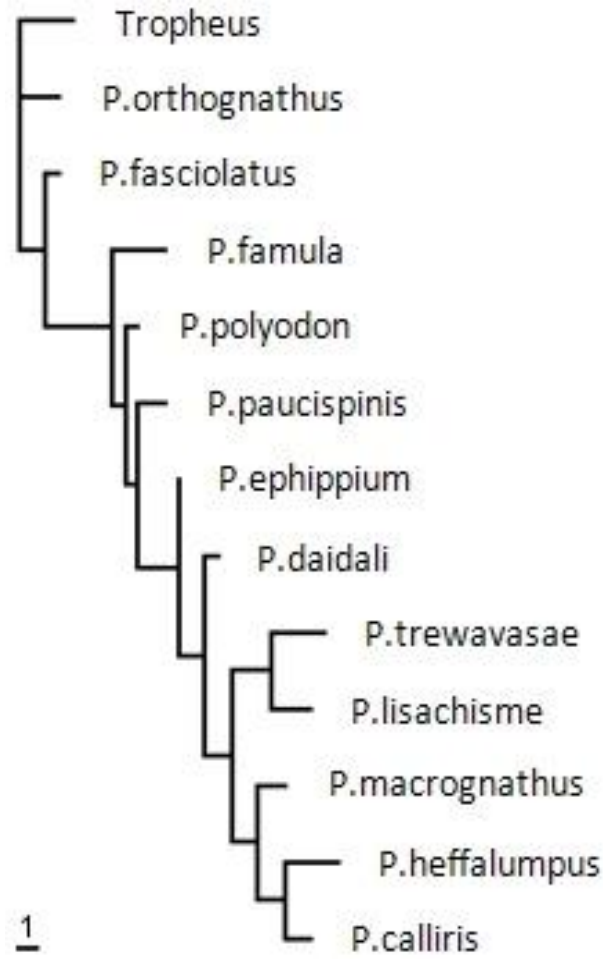

Fig. 5. Strict consensus tree of Petrochromis based on morphological data and parsimony analysis 
bioRxiv preprint doi: https://doi.org/10.1101/280263; this version posted March 12, 2018. The copyright holder for this preprint (which was not certified by peer review) is the author/funder, who has granted bioRxiv a license to display the preprint in perpetuity. It is made available under aCC-BY-NC-ND 4.0 International license.

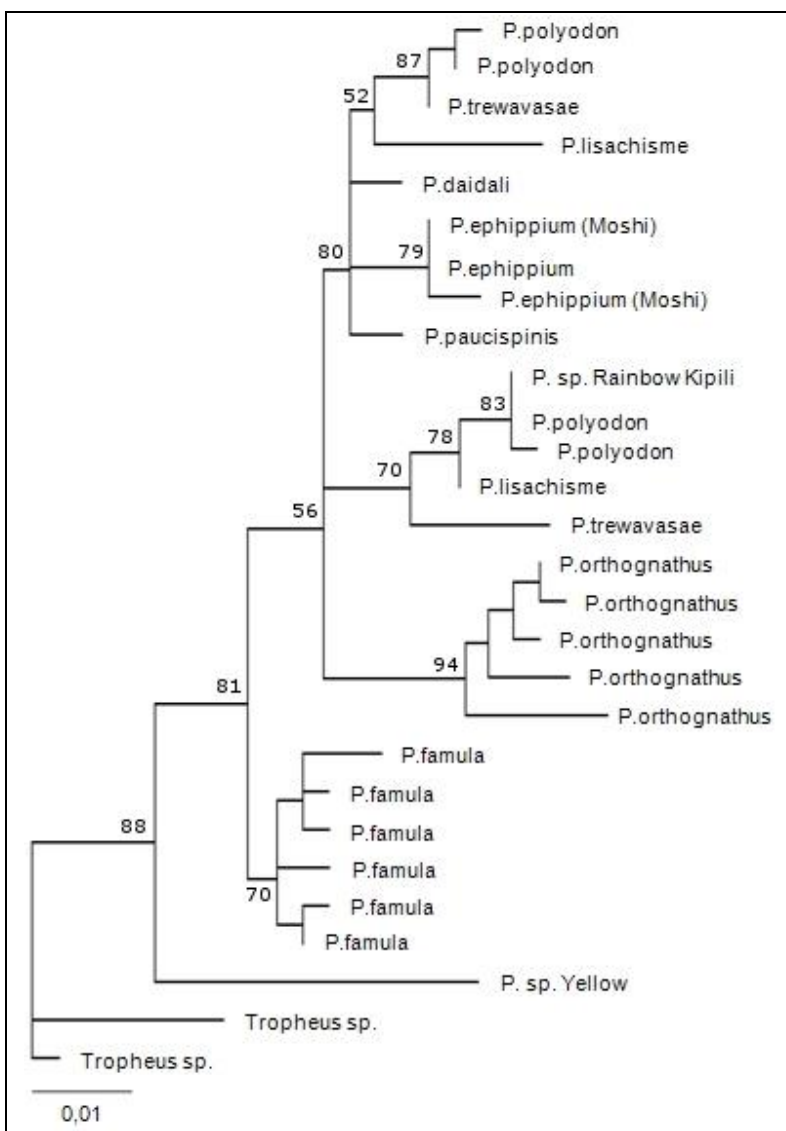

A) Phylogenetic tree, Cytochrome B, Maximum Likelihood

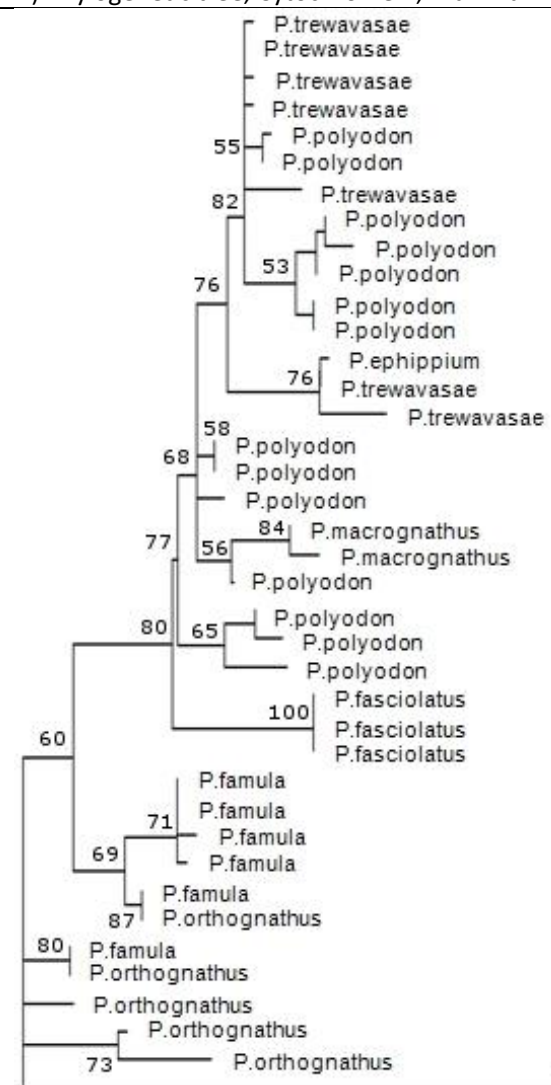

Tropheus sp.

0,1

C) Phylogenetic tree, D-loop, Maximum Likelihood

Fig. 6. Hypotheses of phylogenetic relationships among species of Petrochromis, based on mitochondrial cytochrome $b$ and d-loop sequences, subject to Maximum Likelihood and Bayesian inference analyses.

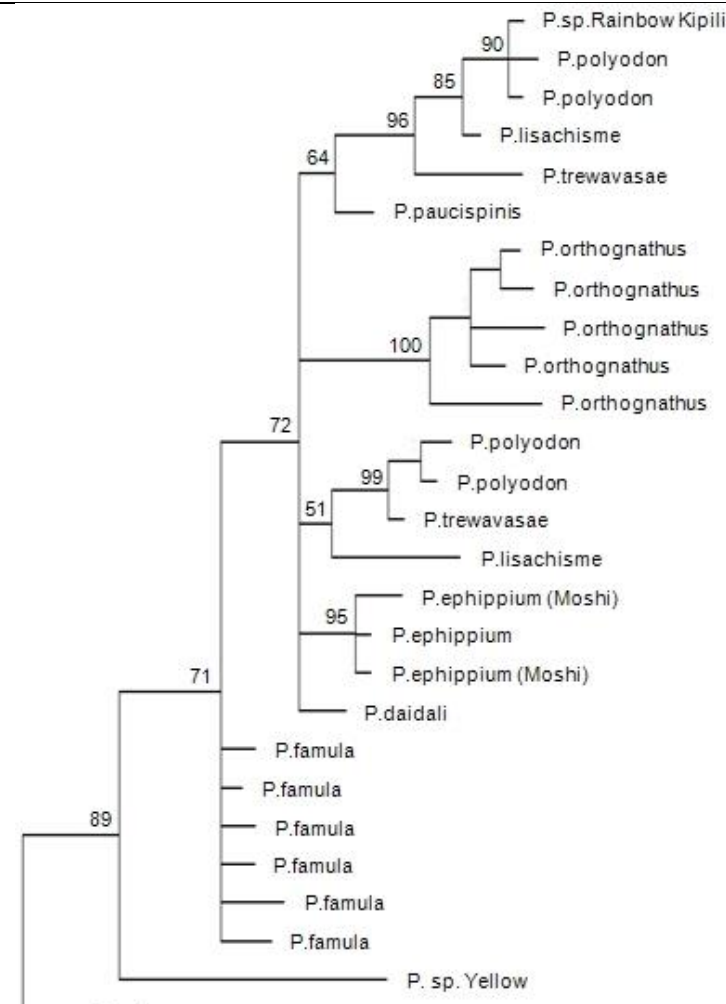

Tropheus sp.

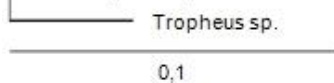

B) Phylogenetic tree, Cytochrome B, Bayesian analysis

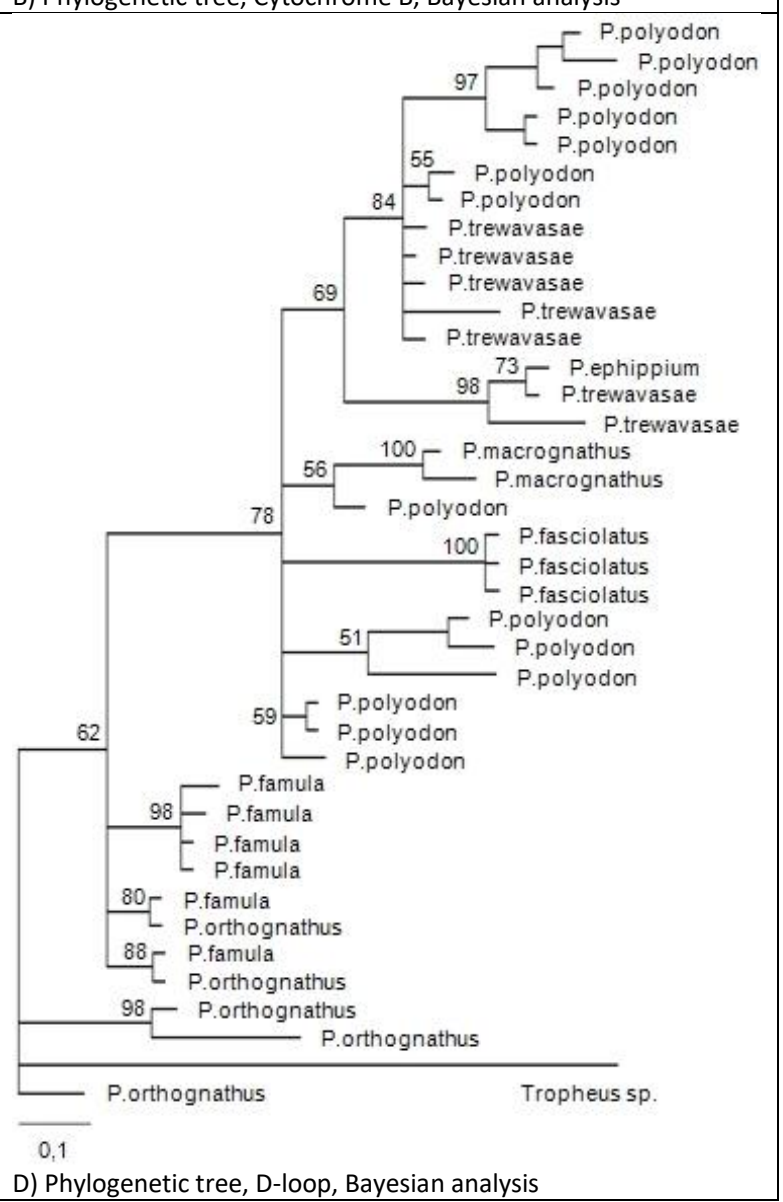

D) Phylogenetic tree, D-loop, Bayesian analysis 


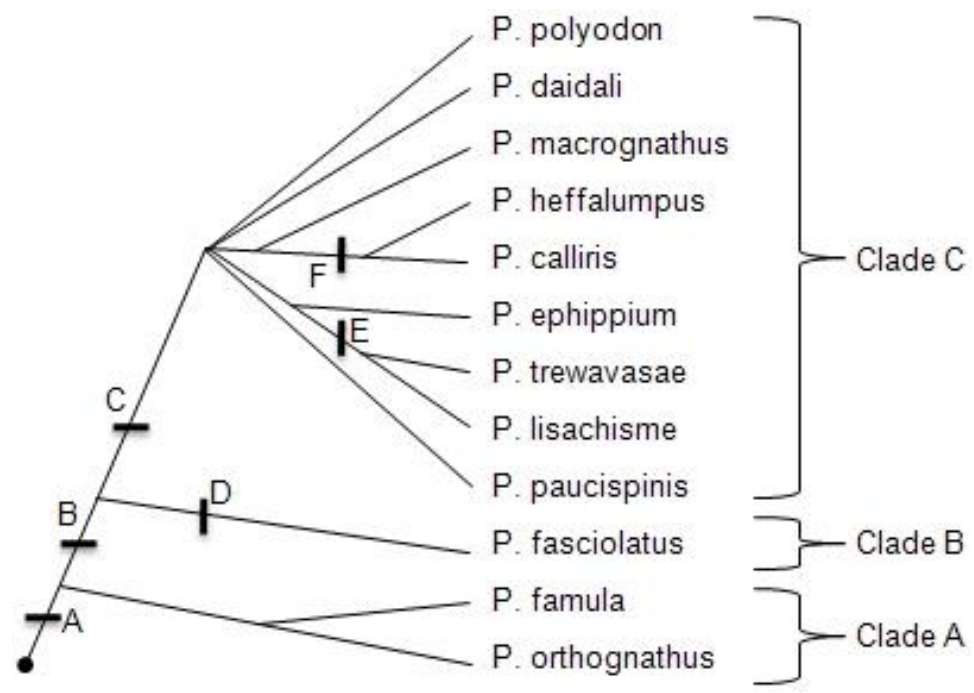

A) 30-31 vertebrae; isognathous jaws; subtruncate caudal fin

B) 31-33 vertebrae; emarginate caudal fin

C) prognathous upper jaw

D) retrognathous upper jaw

E) lunate caudal fin

F) 33-35 vertebrae; subtruncate caudal fin

Fig. 7. Hypothesis of the phylogeny of the genus Petrochromis based on morphological and molecular data

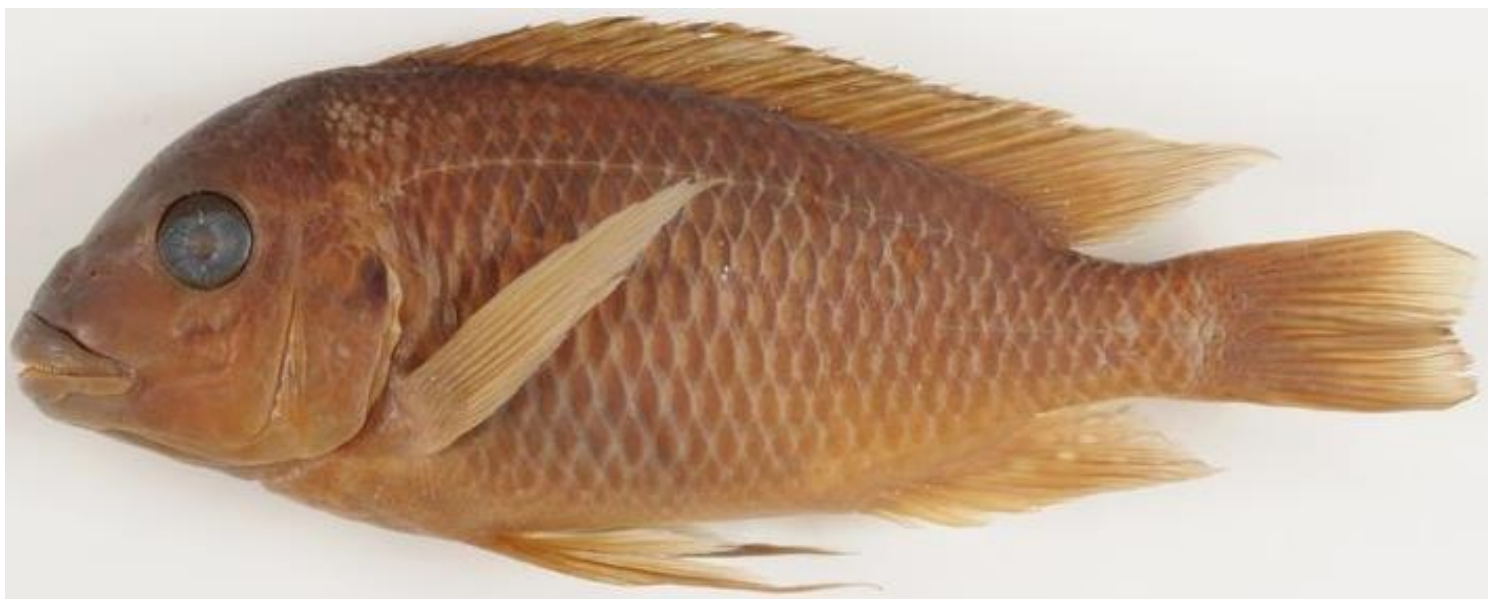

Fig. 8. Petrochromis orthognathus (NRM 17447)

\section{Discussion}

Based on phylogenetic analyses Petrochromis can be divided into three clades (Fig. 7). Clade $A$ consisting of $P$. famula and $P$. orthognathus, clade $B$ consisting of $P$. fasciolatus and clade $C$ consisting of all other Petrochromis. This is similar to Yamaoka's attempt at grouping together different species of Petrochromis based on the number of times a fish opens and closes its mouth per second and per feeding behaviour (Fig. 2) and also fits well with Sturmbauer's molecular tree (Fig. 2). Further study of Petrochromis sp. Yellow is needed to determine its phylogenetic position but molecular results suggests it belongs in clade $A$ (Fig. 6, A-B). Images by Herrmann (1994) show that it has isognathous jaws consistent with clade $A$. The three clades are also recovered in number of vertebrae and jaw position (Fig. 7). A trend towards an increased number of vertebrae in cichlids was suggested by Cichocki (1976) and seems to be the trend also within the genus Petrochromis. 
bioRxiv preprint doi: https://doi.org/10.1101/280263; this version posted March 12, 2018. The copyright holder for this preprint (which was not certified by peer review) is the author/funder, who has granted bioRxiv a license to display the preprint in perpetuity. It is made available under aCC-BY-NC-ND 4.0 International license.

The morphological tree (Fig. 5) suggests placing $P$. fasciolatus between $P$. orthognathus and $P$. famula, contrasting with molecular results, but also similar to Yamaoka's morphological attempt at grouping together different species of Petrochromis based on number of jaw teeth and development of the adductor mandibulae muscles (Fig. 2). The morphological matrix analysis fails to take into account the unique retrognathous upper jaw in P. fasciolatus. No significant support could be found for the morphological tree but it is very similar to the molecular trees. The lack of support is probably mainly due to an insufficient amount of data.

The low resolution in clade $C$ in the molecular analysis (Fig. 6) nevertheless holds points of interest. The sequences of $P$. ephippium and $P$. sp. Moshi are identical and they are of the same species (Fig. 6, A-B). In the trees based on d-loop (Fig. 6, C-D) the single P. ephippium groups with two specimens of $P$. trewavasae from GenBank, suggesting that the identification in GenBank is incorrect. It is noteworthy that two of the new species, $P$. daidali and $P$. paucispinis, fail to group with any other Petrochromis species within clade $C$.

Morphological data (Fig. 5) suggests a clade within clade $C$ comprised of $P$. calliris, $P$. heffalumpus and $P$. macrognathus. That a deep living species like $P$. heffalumpus shares so many character states with $P$. macrognathus, which lives in shallower water is interesting. Closer inspection reveals remarkable similarities when it comes to fin ray counts (Table 5). The third species in this clade, $P$. calliris, is the most ordinary looking Petrochromis amongst the three. It lives shallower than $P$. heffalumpus but deeper than $P$. macrognathus (Table 1). Unfortunately no tissue was available of $P$. calliris or $P$. heffalumpus and these two species could therefore not be included in the molecular analyses. Another clade within clade $C$, also based on morphological results, is comprised of $P$. trewavasae and $P$. lisachisme, the only two species with lunate caudal fins. Yet again the pattern is that a deep-water species, $P$. lisachisme, shares many characters with a particular shallow-water species, $P$. trewavasae.

Basal tree positions (Figs. 5-7) suggest that the "ancestral Petrochromis" might have looked something like $P$. orthognathus (Fig. 8) with isognathous jaws and a relatively elongate body. That the teeth of $P$. orthognathus show regular series indicate that it is less adapted for epilithic algal feeding than e.g. $P$. famula (Yamaoka, 1982), and may also be an ancestral character. The condition is similar to the outgroup Tropheus which also has teeth showing regular series. The only species of Petrochromis except $P$. orthognathus showing regular tooth series is $P$. lisachisme, which is positioned higher up the morphological tree (Fig. 7), but in this species it is probably a reversal reflecting its deeper habitat and its more varied diet not limited to algae. Perhaps Petrochromis sp. Yellow shares this trait also, being placed so close to Tropheus in the phylogeny based on cytochrome $b$ (Fig. 6, A-B), and having isognathous jaws. This however is speculatory since I only worked with its DNA and photographs of this potentially new species.

\section{Acknowledgements}

I wish to thank Sven O. Kullander, Bo Delling and Erik Åhlander of the Swedish Museum of Natural History for their help during this study; I am further grateful to Elizaveta Mattsson, Anders Silfvergrip, Nicklas Wijkmark, Bodil Kajrup, Te Yu Liao, Omar Mechedal, Claes Dannbeck, Bodil Cronholm and Ismail Malikov for their assistance during this study; Magnus and Mikael Karlsson of the African Diving LTD, for supplying Petrochromis specimens and expedition data; Peter Nemeth for supplying tissue samples; Ulf Jondelius and Bertil Borg, professors of the Swedish Museum of Natural History and Stockholm University respectively, for reviewing this article; and a special thanks to the late Fang Kullander and Birgitta Tullberg. 
bioRxiv preprint doi: https://doi.org/10.1101/280263; this version posted March 12, 2018. The copyright holder for this preprint (which was

not certified by peer review) is the author/funder, who has granted bioRxiv a license to display the preprint in perpetuity. It is made available under aCC-BY-NC-ND 4.0 International license.

\section{References}

Barel C., 1977. An introduction to the taxonomy and morphology of the haplochromine cichlidae from Lake Victoria. Netherlands Journal of Zoology 27 (4) 333-389, figs 1-65.

Boulenger G., 1898. Report on the collection of fishes made by Mr. J.E.S. Moore in Lake Tanganyika during his expedition. Proceedings of the General Meetings for Scientific Business of the Zoological Society of London 1898 (pt 3).

Boulenger G., 1902. On new cichlid fishes from Lake Nyassa. Annals and Magazine of Natural History (Series 7) Vol. 10 (no. 55).

Boulenger G., 1914. Diagnoses de poissons noveau. Revue de Zoologique Africaine v. 3 (pt 3), pp. 442-447.

Brichard P., 1989. Pierre Brichard's book of cichlids and all the other fishes of Lake Tanganyika. 544 pages. T.F.H. Publications, Inc.

Cichocki F., 1976. Cladistic history of cichlid fishes and reproductive strategies of the American genera Acharichtys, Biotodoma and Geophagus. Ph. D. dissertation, the University of Michigan, $710 \mathrm{pp}$.

Egger B., S. Koblmuller, C. Sturmbauer \& K. Sefc, 2007. Nuclear and mitochondrial data reveal different evolutionary processes in the Lake Tanganyika cichlid genus Tropheus. Journal BMC Evol. Biol. 7 (1), 137 (2007)

Farías I., G. Ortí, I. Sampaio, H. Schneider \& A. Meyer. The cytochrome b gene as a phylogenetic marker: the limits of resolution for analyzing relationships among cichlid fishes. Journal of molecular evolution 53:89-103 (2001)

Herrmann H., 1985. Alte und neue Petrochromis - und kein ende in sicht. Die Aquarien- und Terrarien-Zeitschrift (DATZ). Vol. 38 (no. 11) pp. 441-444.

Herrmann H. 1994. En förbryllande gul Petrochromis.

Ciklidårsboken, Vol. 4, pp. 14-17. Partille Fohrman Aquaristik.

Sweden.

Kolm N., 2009. Hjärnevolutionen hos Tanganyikacikliderna. Ciklidbladet, Vol. 2 2009. pp. 34-35. Sweden

Konings A., 1988. Tanganyika cichlids. 272 pages. Verduijn Cichlids \& Lake Fish Movies.

Konings A., 1996. Back to nature guide om Tanganyikaciklider. 128 pages. Fohrman Aquaristik. Sweden.

Marijnissen S., E. Michel, R. Daniels, D. Erpenbeck, S. Menken \& F. Schram, 2006. Molecular evidence for recent divergence of Lake Tanganyika endemic crabs (Decapoda: Platythelphusidae). Molecular Phylogenetics and Evolution, Vol. 40, Issue 2. pp. 628634.

Matthes H., 1959. Un cichlidae noveau du lac Tanganyika: Petrochromis orthognathus $n$. sp. Revue de Zoologie et de Botanique Africaines v. 60, 3-4. pp. 335-341.

Matthes H. \& Trewavas E., 1960. Petrochromis famula n. sp., a cichlid fish of Lake Tanganyika. Revue de Zoologie et de Botanique Africaines v. 61, 3-4. pp. 349-357.

Ndembwike J., 2006. Tanzania: The Land and Its People. 2nd ed. 147 pages. Published by G. Mwakikagile.

Poll M., 1948. Descriptions de cichlidae nouveaux, recueillis par la mission hydrobiologique Belge au lac Tanganyika. Bulletin du Musée Royal d'Historie Naturelle de Belgique v. 24 (no. 26)
Sturmbauer C., 2003. Evolution of the tribe Tropheini from Lake Tanganyika: synchronized explosive speciation producing multiple evolutionary parallellism. Hydrobiologia 500: 51-64.

Yamaoka K., 1982 Morphology and feeding behaviour of five species of genus Petrochromis (Teleostei, Cichlidae). Physiol. Ecol. Japan, 19, pp. 57-75.

Yamaoka K. 1983. A revision of the cichlid fish genus Petrochromis from Lake tanganyika, with description of a new species. Japanese Journal of Ichtyology, Vol. 30 (no. 2).

Verheyen E., D. Sherbakov \& B. Nevado, unpublished. Using $m t D N A$ sequences to detect the differential responses of cichlids to environmental changes in Lake Tanganyika. Submitted (2004), Vertebrates, Royal Belgium Institute of Natural Sciences, Rue Vautier 29, Brussels 1000, Belgium

Wagner C., P. McIntyre, K. Buels, E. Michel \& D. Gilbert, unpublished. Diet, not descent, determines intestine length in Lake Tanganyika's cichlid fishes. Submitted 2007, EEB, Cornell University, Corson Hall, Ithaca, NY, 14853, USA

NCBI GenBank (2009): http://www.ncbi.nlm.nih.gov/Genbank/

M. Karlsson \& M. Karlsson; African Diving LTD; field data, 2008

P. Nemeth; aquarist; discussions 2009 